\title{
Factors That Affect the Decisions for Buying Goods and Service on the Internet, Kasem Bundit University
}

\author{
Kitimaporn Choochote ${ }^{1 *}$, Sureeporn Kiatchalermporn ${ }^{2}$ \\ ${ }^{1}$ Department of Information Technology and Communication, Prince of Songkla University, Phuket Campus, \\ Phuket, 83120, Thailand. \\ 2 Faculty of Business Administration, Kasem Bundit University, Bangkok, Bangkok, 10250, Thailand. \\ * Corresponding author. Email: kitimaporn.c@gmail.com \\ Manuscript submitted November 13, 2016; accepted February 14, 2017. \\ doi: 10.17706/ijeeee.2017.7.1.36-50
}

\begin{abstract}
This paper is a research on factors that affect the student's decisions for buying products and services on internet by using data analysis from 345 students as the sample group. The study is used descriptive statistic as basic statistic for describing characteristics of the sample group by using percentage calculation for analyzing sample's personality, mean calculation for analyzing level of opinion, and standard deviation calculation for analyzing level of opinion. The study found that factor of product is the variety of goods and services. Factor of price is the specific explicitly price of goods and services. Factor of distribution channels are easy-to-use and beautiful website. Factors of boosting the market is guaranteed to deliver goods and services. The personnel factor is that employees are knowledgeable about our products and services. Factor of the process serving is a beautiful site that easy to use with clear detailed. Factor of service environment is booking or buying goods and services can be done all in one step.
\end{abstract}

Key words: Consumer behavior, factors affecting, online marketing, online shopping.

\section{Introduction}

This world is getting smaller from what human beings trying to build, whether it's a deep knowledge in every science or technology that rapidly changing world. In the current business, it is not necessary to have large funds for this from the beginning, there was a lot of investment before but it is important to start from the idea that want to do business with creativity, commitment to pursue opportunities, analyze and assess the economic situation, the business environment, and searching how to use the your ability carefully.

E-commerce business is the new model of trading for building and expanding businesses. It is easy to start, easy to reach a common target group around the world at anywhere and anytime, and consistent with the social-economic condition that consumers want their convenience in buying goods and services. Businesses must be developed and improved for the race to find market shares, to expand the network, and the most important thing, for the survival of the business itself.

For the use of information and communication technologies in households of the country Thailand, The National Bureau of statistics has made continuous exploration every year to keep the population aware the use of a computer, the Internet and mobile phone, and characteristics and behavior in the use of various technologies, including knowing the number of households with information and communication technology devices such as telephone, fax, computer and internet connection in the household, etc. The survey method is used to interview the head of the household and the household members aged 6 years 
and up from sample group of household around 83,880 households. Results of the survey are as follows:

The use of computers, the Internet, and mobile phones in the total population aged 6 years and older approximately 62.6 million people, survey results found that there were 21.8 million computer users (34.9 percent), 24.6 million Internet users (39.3 percent) and 49.6 million mobile phone users (79.3 percent).

When considering comparative trends in the use of computers, the Internet and mobile phones of the population aged 6 years and over a five year period during the year $2554-2558$ found that computer users increased from 32.0 percent (19.9 million users) to 34.9 percent (21.8 million users), Internet users increased from 23.7 percent (14.8 million users) to 39.3 percent (24.6 million users) and mobile phone users increased by 66.4 percent (41.4 million users) to 79.3\% (49.6 million users). For appearance and behavior while using the Internet, and comparison between the right to use the Internet to browse the male and female, it found that the use of the Internet of male and female, which is not much different from the data from the 2011 - 2015, increases continuously.

The use of the Internet by different age groups were found that The population in the age group of 15 24 years old have the highest Internet usage at 76.8 percent, in the age group of 25-34 years old at 60.1 percent, in the age group of 6-14 years age at 58.0 percent, the age group of $35-49$ years old at 31.8 percent, and in the age group of 50 years old or more has only 9.6 percent respectively.

For places to use the Internet, this study found that the majority group used internet in various locations on their mobile/portable devices such as Notebook, Tablet at 81.7 percent, usage at home or residential usage at 67.1 percent, 34.9 percent as education, and 34.2 percent as work activities. For activities on the Internet, mostly using Social Network (Facebook, Twitter, Google Plus, Line, Instagram) at 88.6 percent, use to download Photo/video/music/movies/games or play games/watch movies/ listen to music or radio at 87.4 percent, use in uploading images/video/music/ photography/ software to share at 59.1 percent, and use of Web sites and send or receive e-mail at 44.6 percent. For the frequency of Internet use, this study found that Internet use 5-7 days in 1 week at 73.1 percent, followed by the use of 1-4 days in 1 week of 25.5 percent [1].

From the above information, The National Bureau of statistics has undertaken to collect data from the trader, during the months of March to May, by sending officials of 2557 National Statistics Office released an interview to gather information. Details of the survey results conclude that the majority of business entrepreneurial type B2C is 80.4 percent, followed by the entrepreneurship category section at 18.2 percent, and B2B operators excluded B2G type employment procurements from Government by e-Auction are only 1.4 per cent. In an overview of the business, they are mainly located in the fashion industry group and costume jewelry (26.4 percent), followed by a group of tourist hotels and resorts (23.3 percent), computer groups/electronic devices and the Internet (18.7 percent), other types of item groups (16.5 percent), public services (6.2 percent), printing/office supplies (5.4 percent), and automotive products ( 3.5 percent).

For business operations, they are mainly selling goods and services through electronic and with the sale at 61.6 percent, sold through electronic parts only at 37.7 percent, and the remaining 0.7 percent sold through both electronics and the sale of any kind, such as sending an employee to direct sales or sales, etc. For the method used in the customer care of the business, which has more than one answer, the answer is found that most officers receive a call (Call Center) at 76.7 percent, use email or send questions on website at 73.1, use Social media like Facebook and twitter or Line at 30.8 percent, using Live Chat or client chat systems such as MSN or Skype at 15.8 percent [2], [3].

From accessibility to technology and the Internet usage of each person or family, this is a time to say that the business must increase sales via the Internet as another channel or use internet as main channel. Business also had to wait the change of cultural confidence and buying of goods and services via the Internet in the future, with the challenges ahead of the operator or the user indirectly [4], [5]. There is a lot 
of research, both domestic and foreign. It found that the main factors of a successful e-commerce business assumptions is that trust in the operator's Web site, followed by other factors, that means the business must create the belief to consumed first?

Changes of electronic commerce are gradually increasing as the adaptation for the survival of the business and the public sector-driven, that consistent with the behavior of consumers, as the social trends. That's where researchers are interested in the views of the nowadays consumers about what are their opinions on buying goods and services via the Internet, and what factors are there? By a research study from undergraduate students of business administration faculty, with the age range that is consistent with the National Bureau of statistics, the study said that when considering the use of the Internet by various age groups, the age group of 15-24 years old has the highest Internet usage [6], [7].

\section{Literature Reviews}

This research has studied the relevant information to achieve in-depth understanding about the decision to buy goods and services via the Internet of new generation, which is a student that age between 18-26 years old, review the concepts and theories of buying decision, factors of buying decision, and forms of e-commerce on the Internet marketing mixture.

\subsection{Concepts and Theories of Buying Decision}

The decision is to choose one from many choices, using the reasons which process since buying started until the item is received, in order to contribute to achieving the goals and meet the best. Kotler (2000:167-178) explains that the process of buying decision should contain is marketers need to know who is the actual buyer by users involved include: originator, instructions, those with influence in buying decisions, real buyers, and users of goods and services [8].

Consumer behavior in the decision for buying goods and services via Internet has many factors involved, both personal characteristics factor and goods or service factor. Personal factors are gender, age, income, living conditions, education, attitude, satisfaction, etc. Goods or services factors are the type of goods and services, or store format, reliability, safety, transport, etc. These factors influence the consumer's decision to buy approved as seen in Figure 1 Online Consumer Behavior [9].

Marketing mix of the product is based contains 4Ps but Kotler (1997) has opinion that their marketing mix of service market is consist of 7Ps; 1) Product: P1 is products, 2) Price: P2 is prices, 3) Place: P3 is the distribution channel, 4) Promotion: P4 is a marketing campaign, 5) People: P5 is employees, 6) Process: P6 is the process of providing services, and 7) Physical Evidence: P7 is the physical environment [10].

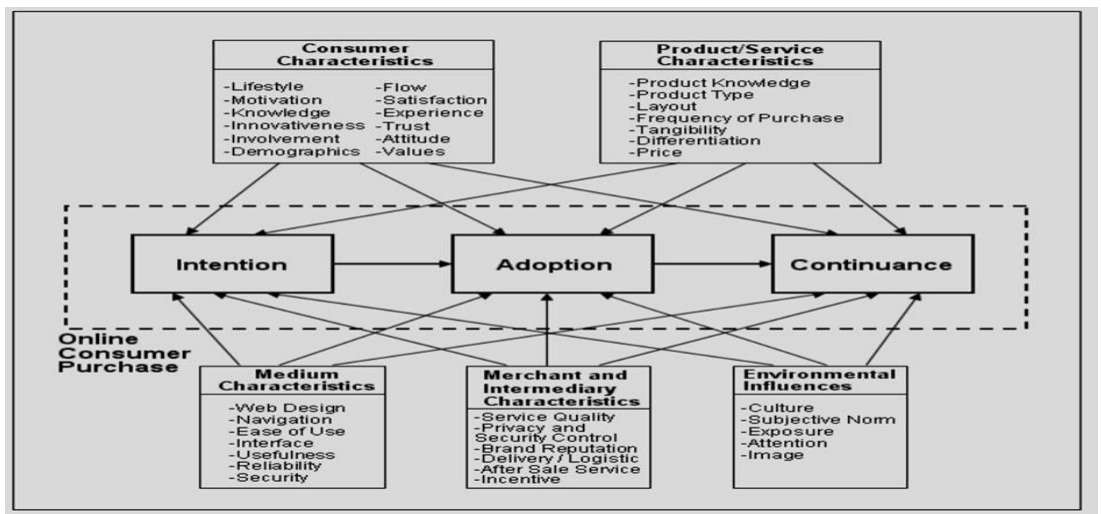

Fig. 1. Online consumer behavior (Chau et al. 2000; Lin \& Lu, 2000).

Marketing mix in view of customers consists of these following; 1) Customer Value: C1 is the value that 
the customer will receive, 2) Cost to Customer: C2 is the cost, 3) Convenience: C3 is convenience, 4) Communication: $\mathrm{C} 4$ is the communication, 5) Caring: $\mathrm{C} 5$ is the customer care, 6) Completion: $\mathrm{C} 6$ is achieved in response to the requirements, and 7) Comfort: $\mathrm{C} 7$ is comfort [11]-[13].

\subsection{Forms of Electronic Commerce on the Internet}

The model of traders and the prospects of traders for doing business on the Internet have Business to Business (B2B) transactions between commercial organizations which mostly take the form of establishing a group of members such as the wholesale business and importing business, and Business to Consumer (B2C) transactions between retails to consumers worldwide, and Consumer to Consumer (C2C) transactions between consumers and consumers. It uses technology as channels of exchange with each other [14].

Items in the e-commerce system are tangible goods (Goods) and intangible goods (Services) and information (Information) [15].

To buy goods and services via Internet, there is a very simple procedure. Consumers can buy goods and services from anywhere on the Internet network, order according to the terms of the shop, pay by cash or credit card, and receive items at the address provided to the shops [16]-[19].

\subsection{Conceptual Framework of Research}

The concept of research framework is to study factors that affect the decision to buying goods and services via the internet on students of the Faculty of business administration, Kasem Bundit University, by studying the related theory and research as shown in Fig. 2.

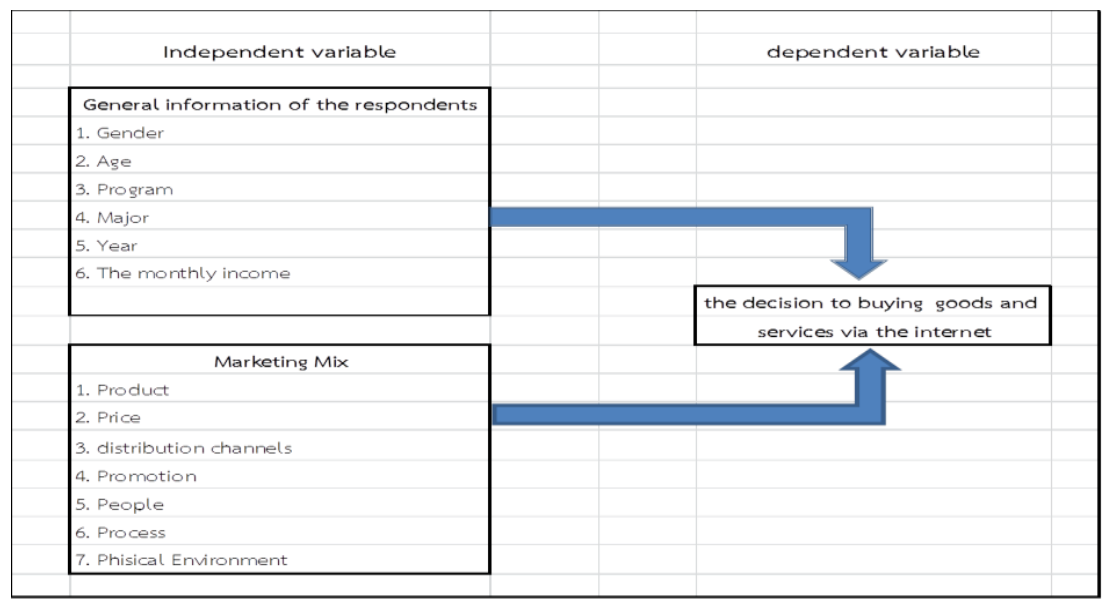

Fig. 2. The concept of research framework.

\section{The Objective of the Research}

To learn more about factors that affect the decision to buy goods and services via the Internet on normal program students from the Faculty of business administration, Kasem Bundit University.

\section{Methodology}

The population used in this study is the normal program student from faculty of business administration, Kasem Bundit University, that have 2081 students from Bachelor degree of business administration and 411 students from Bachelor degree of accounting courses, 2489 students in total as following:

\subsection{Samples Group Used in Research}


The sample group in this research study is 345 normal program students from faculty of business administration, Kasem Bundit University. This sample group calculated by the size of the samples and calculation formula of Taro Yamane (1967) by assigning 95\% confidence and using a split-sample class by randomly sample coincidence (Accidental sampling) based on the number of students that are defined.

\subsection{Statistics Used in Data Analysis}

In this study, researchers have taken their received questionnaire to check all validation of the questionnaire, then code the questionnaire (Coding) and analyze the data processed by using a ready-to-use program. Using the calculated value of the statistic is using descriptive statistics as the basic statistics to explain natures of the sample groups which consist of percentage for data analysis of personal characteristics, sample average (Mean)for analyze level of reviews, and the standard deviation for the analyze level of reviews.

An analysis of the opinions of a sample with the average, the standard deviation, and the percentage scale by using the following criteria; $1.00-1.50$ refer to lowest level of buying decision, $1.51-2.50$ refer to low level of buying decision levels, 2.51 - 3.50 refer to medium level of buying decisions, $3.51-4.50$ refers to higher level of buying decisions, and $4.51-5.00$ refers to the highest level of buying decision.

\section{The Results of the Data Analysis}

The analysis of this information, the objective is to learn about the factors that affect the decision to buying goods and services via the Internet on the normal program students from Faculty of business administration, Kasem Bundit University. The result of this study will present in statistic lecture presentation which portrays the information in the table form, the average, and percentage by dividing into four parts; Section A is General information of the respondent, Section B is internet usage information, Section $C$ is shopping habits via Internet, and Section D is decision to buy goods or services via the Internet on normal program students from the Faculty of business administration, Kasem Bundit University.

\subsection{General Information of the Respondents}

General information is questions about general information of the respondent's such as gender, age, subjects, faculty, seniority, and the average income per month, as follows:

Table 1. Number and Percentage on Gender of Respondents

\begin{tabular}{|c|c|c|}
\hline Gender & Frequency & Percent \\
\hline Male & 80 & 23.2 \\
\hline Female & 265 & 76.8 \\
\hline Total & 345 & 100 \\
\hline
\end{tabular}

Study results as shown in Table 1 as above. This study found that the majority of respondents are female, total of 265 people or 76.8 percent, more than 80 male or 23.2 percent or respondents.

Table 2. Number and Percentage on Age of Respondents

\begin{tabular}{|l|c|c|c|}
\hline & Age & Frequency & Percent \\
\hline $2-18$ years & 193 & 55.9 \\
\hline $23-21$ years & 145 & 42.0 \\
\hline $26-24$ years & 7 & 2.0 \\
\hline \multicolumn{2}{r|}{ Total } & 345 & 100 \\
\hline
\end{tabular}

Study results as shown in Table 2 as above. This study found that the majority of respondents are 
between the ages of 18 - 20 years old, a total of 193 people which representing 55.9 per cent, followed by those between the ages of 21 - 23 years old, total of 145 people which representing 42 percent, and those with the age range between $24-26$ years old, total of 2 people which representing 7 percent.

Table 3. Number and Percentage on the Program of the Respondent

\begin{tabular}{|c|c|c|}
\hline \multicolumn{1}{|c|}{ Program } & Frequency & Percent \\
\hline Bachelor of Business Administration Program & 288 & 83.5 \\
\hline Bachelor of Accountancy & 57 & 16.5 \\
\hline \multicolumn{1}{|c|}{ Total } & 345 & 100 \\
\hline
\end{tabular}

Study results as shown in Table 3 as above. This study found that most respondents study in Bachelor of Business Administration Program, total of 288 people or 83.5 percent, and other study in Bachelor of Accountancy, total of 57 people or 16.5 percent.

Table 4. Number and Percentage on Subject of the Course of Respondents

\begin{tabular}{|l|c|c|}
\hline \multicolumn{1}{|c|}{ Major } & Frequency & Percent \\
\hline Management & 45 & 13.0 \\
\hline Finance and Banking & 19 & 5.5 \\
\hline Marketing & 30 & 8.7 \\
\hline Business Computer & 39 & 11.3 \\
\hline Human resource Management & 37 & 10.7 \\
\hline International Transportation (INTERNATIONAL TRANSPORTATION) & 117 & 33.9 \\
\hline Retail and Franchise Business Management & 57 & 0.3 \\
\hline Accounting Total & 345 & 16.5 \\
\hline \multicolumn{1}{|c|}{ T) } & 100 \\
\hline
\end{tabular}

Study results as shown in Table 4 as above. This study found that most respondents are the student study in the International Transportation, total of 117 people or 33.9 percent. Others are 57 people who study in Accounting, or 16.5 percent, 45 people who study in Management, or 13 percent, 39 people who study Business Computing, or 11.3 percent, 37 people who study Human Resources Management, or 10.7 percent, 30 people who study Marketing, or 8.7 percent, 7 people who study Banking, or 5.5 percent, and 7 people who study Finance, or 5.5 percent, and 1 people who study the Retail and Franchise Business Management, or 0.3 percent, respectively.

Table 5. Number and Percentage on the Seniority of the Respondents

\begin{tabular}{|c|c|c|}
\hline 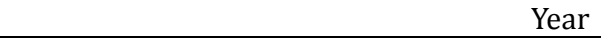 & Frequency & Percent \\
\hline 1 & 118 & 34.2 \\
\hline 2 & 96 & 27.8 \\
\hline 3 & 72 & 20.9 \\
\hline 4 & 59 & 17.1 \\
\hline 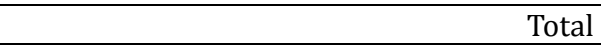 & 345 & 100 \\
\hline
\end{tabular}

Study results as shown in Table 5 as above. This study found that most respondents are newbie or new students, total number of 118 people which representing 34.2 percent. Others are sophomores with total number of 96 people representing 27.8 percent, junior with total number of 72 people representing 20.9 percent, and senior with total number of 59 people representing 17.1 percent.

Study results as shown in Table 6 as above. This study found that most of them have their monthly income lower than $4,000 \mathrm{Baht}$, total number of 209 people representing 60.6 percent. Others are 70 people who has monthly income 4,000-6,000 Baht representing 20.3 percent, 35 people who has monthly income 6,001 - 8,000 Baht representing 10.1 percent, 15 people who has monthly income 8,001 - 10,000 Baht 
representing 4.3 percent, 12 person who has monthly income 10,001 - 12,000 Baht representing 3.5 percent, 2 people who has monthly income 14,001 - 16,000 Baht representing 0.6 percent, and 2 people who has monthly income more than 160,000 Baht representing 0.6 percent, respectively.

Table 6. Number and Percentage on the Monthly Income of Respondents

\begin{tabular}{|l|c|c|}
\hline & Frequency & Percent \\
\hline lower than 4,000 Baht the monthly income & 209 & 60.6 \\
\hline $4,000-6,000$ Baht & 70 & 20.3 \\
\hline $6,001-8,000$ Baht & 35 & 10.1 \\
\hline $8,001-10,000$ Baht & 15 & 4.3 \\
\hline $10,001-12,000$ Baht & 12 & 3.5 \\
\hline $14,001-160,000$ Baht & 2 & .6 \\
\hline more than 16,001 Baht & 2 & .6 \\
\hline & 345 & 100 \\
\hline
\end{tabular}

\subsection{Information on Using the Internet}

Information about using the Internet is questions about the connecting system, location, frequency, duration of usage, and the number of times buying goods and services via internet. Data shown as follows:

Table 7. Number and Percentage of Computers or Communication Devices That Connect to Internet Network in Private Residential

\begin{tabular}{|c|c|c|}
\hline $\begin{array}{l}\text { computers or communication devices that connect } \\
\text { to internet network in private residential }\end{array}$ & Frequency & Percent \\
\hline Have & 313 & 90.7 \\
\hline Don't have & 32 & 9.3 \\
\hline Total & 345 & 100 \\
\hline
\end{tabular}

Study results as shown in Table 7 as above. This study found that most respondents have access to a computer or communication device that connects to internet network in their private residential, total of 313 people representing 90.7 percent. Other respondents are 32 people who have not intended for personal use in a residential, representing 9.3 percent.

Table 8. The Number and Percentage of Devices Mostly Use to Connect to the Internet

\begin{tabular}{|l|c|c|}
\hline \multicolumn{1}{|c|}{ devices mostly use to connect to the Internet } & Frequency & Percent \\
\hline Mobile phone/ Smart phone & 277 & 80.3 \\
\hline PC & 24 & 7.0 \\
\hline Notebook & 39 & 11.3 \\
\hline Tablet & 3 & .9 \\
\hline Other Total & 2 & .6 \\
\hline \multicolumn{2}{|c|}{345} & 100 \\
\hline
\end{tabular}

Table 9. The Number and Percentage of Location Most Commonly Used the Internet

\begin{tabular}{|l|c|c|}
\hline \multicolumn{1}{|c|}{ location most commonly used the Internet } & Frequency & Percent \\
\hline Home & 198 & 57.4 \\
\hline Dorm & 30 & 8.7 \\
\hline In university and dorm & 108 & 31.3 \\
\hline internet café & 5 & 1.4 \\
\hline Other & 4 & 1.2 \\
\hline \multicolumn{2}{|c}{345} & 100 \\
\hline
\end{tabular}

Study results as shown in Table 8 as above. This study found that most respondents mostly use Mobile phone/Smart phone to connect the internet, total of 277 people representing 80.3 percent. Other 
respondents are 39 people using the Notebook representing 11.3 percent, 24 people using PC representing 7.0 percent, 3 people using Tablet representing 0.9 percent, and 2 people using other devices representing 0.6 percent, respectively.

Study results as shown in Table 9 as above. This study found that most respondents most often use internet at home, total number of 109 people representing 57.4 percent. Other respondents are 108 people who use internet in their university and its dorm representing 31.3 percent, 30 people who use internet in their dorm representing 8.7 percent, 5 people who use internet at internet café representing 1.4 percent, and 4 people who use internet in other places representing 1.2 percent.

Table 10. Percentage of the Amount and Frequency of Use of the Internet (Per Week)

\begin{tabular}{|l|c|c|}
\hline \multicolumn{1}{|c|}{ amount and frequency of use of the Internet (per week) } & Frequency & Percent \\
\hline less than 2 days & 9 & 2.6 \\
\hline 3-4 day & 27 & 7.8 \\
\hline 5 - 6 day & 25 & 7.2 \\
\hline Everyday & 284 & 82.3 \\
\hline \multicolumn{2}{|c|}{ Total } & 100 \\
\hline
\end{tabular}

Study results as shown in table 10 as above. This study found that the frequency of Internet use per week of most respondents is every day, total number of 284 people representing 82.3 percent. Other respondents are 27 people who use internet 3-4 days per week representing 7.8 percent, 25 people who use internet 5 6 days per week representing 7.2 percent, and 9 people who use internet less than 2 days representing 2.6 percent.

Table 11. Percentage of the Amount and Period of Use the Internet Each Day (Average)

\begin{tabular}{|l|c|c|}
\hline \multicolumn{1}{|c|}{ amount and period of use the Internet each day (average) } & Frequency & Percent \\
\hline $1-2$ hours & 41 & 11.9 \\
\hline 3 - hours & 121 & 35.1 \\
\hline 6 - 8 hours & 91 & 26.4 \\
\hline more than 8 hours & 92 & 26.7 \\
\hline \multicolumn{2}{|c}{345} & 100 \\
\hline
\end{tabular}

Study results as shown in Table 11 as above. This study found that the most frequency duration of using the Internet each day of most respondents is 3-5 hours per day, total number of 121 people representing 35.1 percent. Other respondents are 92 people who use internet more than 8 hours per day representing 26.7 percent, 91 people who use internet 6 - 8 hours per day representing 26.4 percent, and 41 people who use internet less than 2 hours per day representing 11.9 percent.

Table 12. Percentage of the Amount and the Number of Times to Buy Various Goods via the Internet

\begin{tabular}{|c|c|c|}
\hline amount and the number of times to buy various goods via the Internet (per month) & Frequency & Percent \\
\hline less than 2 times & 185 & 53.6 \\
\hline $2-3$ times & 101 & 29.3 \\
\hline $4-5$ times & 22 & 6.4 \\
\hline more than 5 times & 37 & 10.7 \\
\hline Total & 345 & 100 \\
\hline
\end{tabular}

Study results as shown in Table 12 as above. This study found that the most frequency of number of times to buy various goods via the Internet (per month) is less than 2 times, total of 185 people representing 53.6 percent. Other respondents are 101 people who buy goods 2-3 times per month representing 29.3 percent, 37 people who buy goods more than 5 times per month representing 10.7 percent, and 22 people who buy goods 4-5 times per month representing 6.4 percent. 


\subsection{Shopping Habits on Internet}

Information about shopping habits on Internet is the question about the type of items, the average price of goods and services, payment method, reason for buying, and problems found on buying goods and service via internet from experience of respondents.

Table 13. Percentage of the Amount and Type of Selected Items Buy Goods and Services via the Internet

\begin{tabular}{|l|c|c|}
\hline \multicolumn{1}{|c|}{ type of selected items } & Frequency & Percent \\
\hline clothes & 234 & 33.6 \\
\hline computer/Hardware & 23 & 3.3 \\
\hline books & 54 & 7.7 \\
\hline shoes / leatherwork & 100 & 14.3 \\
\hline jewelry / hat & 67 & 9.6 \\
\hline sports equipment's & 29 & 4.2 \\
\hline game / music & 46 & 6.6 \\
\hline foods & 27 & 3.9 \\
\hline flights & 58 & 8.3 \\
\hline booking a hotel & 25 & 3.6 \\
\hline rent vehicles & 7 & 1.0 \\
\hline buying a trip & 15 & 2.2 \\
\hline other & 12 & 1.7 \\
\hline
\end{tabular}

Study results as shown in table 13, all of 345 respondents are people used to buy goods and services via Internet. The type of goods can be classified as follows:

234 people or 33.6 percent has been bought Fashion clothing. 100 people or 14.3 percent has been bought shoes / leatherwork. 67 people or 9.6 percent has been bought jewelry or hat. 58 people or 8.3 percent has been bought flights. 54 people or 7.7 percent has been bought books. 46 people or 6.6 percent has been bought game or music sheets. 29 people or 4.2 percent has been bought sports equipment's. 27 people or 3.9 percent has been bought foods. 25 people or 3.5 percent has been booked hotels. 23 people or 3.3 percent has been bought computer/hardware. 15 people or 2.2 percent has been bought tours. 7 people or 1.0 percent has been rent vehicles. And 12 people or 1.7 percent has been bought other items.

Table 14. Percentage and Amount of Money Using in Each Time of Buying

\begin{tabular}{|c|c|c|}
\hline money using in each time of buying & Frequency & Percent \\
\hline $1-100$ Baht & 30 & 8.7 \\
\hline $101-500$ Baht & 152 & 44.1 \\
\hline $501-1,000$ Baht & 88 & 25.5 \\
\hline $1,001-2,000$ Baht & 41 & 11.9 \\
\hline $2,001-3,000$ Baht & 17 & 4.9 \\
\hline $3,001-4,000$ Baht & 8 & 2.3 \\
\hline $4,001-5,000$ Baht & 2 & .6 \\
\hline more than 5,000 Baht & 7 & 2.0 \\
\hline Total & 345 & 100 \\
\hline
\end{tabular}

Study results as shown in table 14 as above. This study found most respondents use $101-500$ Baht for each time of buying, total of 152 people representing 44.1 percent. Other respondents are 88 people who use $501-1,000$ Baht for each time of buying representing 25.5 percent, 41 people who use 1,001 - 2,000 Baht for each time of buying representing 11.9 percent, 30 people who use less than 100 Baht for each time of buying representing 8.7 percent, 17 people who use 2,001 - 3,000 Baht for each time of buying representing 4.9 percent, 8 people who use 3,001 - 4,000 Baht for each time of buying representing 2.3 percent, 2 people who use 4,001 - 5,000 Baht for each time of buying representing 0.6 percent, and 7 people who use more than 5,000 Baht for each time of buying representing 2 percent, respectively. 
Study results as shown in table 15 as above. For goods and services payment, this study found that most respondents pay for goods and services by using wire transfer to the seller's bank account, total of 202 people representing 58.6 percent. Other respondents are 60 people who pay via bank debit representing 17.4 percent, 45 people who pay by counter payment representing 13 percent, 21 people who pay by credit card representing 6.1 percent, 10 people who pay cash on delivery representing 2.9 percent, 5 people who pay cash upon receipt of the goods representing 1.4 percent, and 2 people who pay on cash check representing 0.6 percent, respectively.

Table 15. Percentage and Amount of Payment Method for Ordered Goods and Services

\begin{tabular}{|l|c|c|}
\hline \multicolumn{1}{|c|}{ payment method for ordered goods and services } & Frequency & Percent \\
\hline pay via bank debit & 60 & 17.4 \\
\hline counter payment & 45 & 13.0 \\
\hline credit card & 21 & 6.1 \\
\hline pay on cash check & 2 & .6 \\
\hline transfer to the seller's bank account & 202 & 58.6 \\
\hline cash on delivery & 5 & 2.9 \\
\hline pay cash upon receipt of the goods Total & 345 & 1.4 \\
\hline \multicolumn{1}{|c}{} \\
\hline
\end{tabular}

Table 16. Percent and Amount of Why People Buy Goods and Services via Internet

\begin{tabular}{|l|c|}
\hline \multicolumn{1}{|c|}{ why people buy goods and services via Internet } & Frequency \\
\hline ordering experiments & 17 \\
\hline convenient ordering & 215 \\
\hline price comparison of products & 62.3 \\
\hline promotions & 6.4 \\
\hline only available on internet & 39 \\
\hline No time to buy at the store & 11.3 \\
\hline & 4.9 \\
\hline
\end{tabular}

Study results as shown in table 16 as above. For why buying goods and services via the Internet, this study found that most respondents order because of convenient ordering, total of 215 people representing 62.3 percent. Other respondents are 39 people who buy because of promotions representing 11.3 percent, 35 people who buy because of shopping time representing 10.1 percent, 22 people who buy because of price comparison of products representing 6.4 percent, 17 people who buy because of ordering experiments representing 4.9 percent, and 17 people who buy because of only available on internet representing 4.9 percent.

Table 17. Percentage and Amount of the Barriers Encountered by Buying Goods or Services via the Internet

\begin{tabular}{|l|c|c|}
\hline \multicolumn{1}{|c|}{ barriers encountered by buying goods or services via the Internet } & Frequency & Percent \\
\hline the goods are not the same as in the advertisements & 102 & 29.6 \\
\hline no product quality & 25 & 7.2 \\
\hline complex order process & 25 & 7.2 \\
\hline the goods delayed & 51 & 14.8 \\
\hline transportation costs & 59 & 17.1 \\
\hline no convenient on goods returning & 20 & 5.8 \\
\hline no guarantee & 13 & 3.8 \\
\hline no actual & 46 & 13.3 \\
\hline other & 4 & 1.2 \\
\hline & 345 & 100 \\
\hline
\end{tabular}

Study results as shown in Table 17 as above. This study found that most barriers encountered by respondents while buying goods or services via the Internet is the goods are not the same as in the advertisements, total of 102 people representing 29.6 percent. Other barriers encounter by respondents while buying goods or services via internet are transportation costs with total number of 59 representing 17.1 percent, the goods delayed with total number of 51 persons representing 14.8 per cent, no actual with 
46 people representing 13.3 percent, no product quality with 25 people representing 7.2 percent, complex order process with 25 people representing 7.2 percent, no convenient on goods returning with 20 people representing 5.8 percent, no guarantee with 13 people representing 3.8 percent, and other reasons with 4 people representing 1.2 percent.

\subsection{The Decision to Buy Goods or Services via the Internet on Normal Program Students from Kasem Bundit University}

Information about buying decision to buy goods or services via the Internet is questions about marketing mix as products, price, distribution channels, promotion, people, service processes, and physical environment. All these questions measure the level of factors that affect the decision, based on normal program students from the Faculty of business administration, Kasem Bundit University, towards the buying of goods and services via Internet by using the average and standard deviation.

Table 18. Average and Standard Deviation of Product Factors That Could Affect the Decision to Buy Goods or Services via the Internet

\begin{tabular}{|l|c|c|c|}
\hline $\begin{array}{c}\text { product factors that could affect the decision to buy goods or services } \\
\text { via the Internet }\end{array}$ & Mean & S.D. & Level \\
\hline the reputation and image of the goods and services & 3.93 & .718 & High \\
\hline quality products and good service & 3.97 & .777 & High \\
\hline the reliability of products and services & 3.84 & .869 & High \\
\hline preview products and services & 3.85 & .834 & High \\
\hline the variety of products and services & 4.02 & .866 & High \\
\hline Total of product factors & 3.92 & .608 & High \\
\hline
\end{tabular}

Table 18 found that overall factors which affect the decision to buy goods or services via the Internet are in high level, having 3.92 as the total average. When analyzing by orders, this study found that highest average factor is variety of products and services, having 4.02 as average. The other factors are quality products and good service with average of 3.97, the reputation and image of the goods and services with average of 3.93, preview products and services with average of 3.84, and reliability of goods and services with average of 3.84 as the smallest average, respectively.

Table 19. The Average and Standard Deviation of the Price Factors That Influence the Decision to Buy Goods or Services via the Internet

\begin{tabular}{|c|c|c|c|}
\hline $\begin{array}{l}\text { the price factors that influence the decision to buy goods or services via } \\
\text { the Internet }\end{array}$ & Mean & S.D. & Level \\
\hline the clearly price of goods and services & 3.97 & .841 & High \\
\hline reasonable price compared to the quality & 3.85 & .782 & High \\
\hline price comparison between products & 3.78 & .814 & High \\
\hline cheaper goods and services than other buying methods & 3.81 & .885 & High \\
\hline the facility to pay for the service & 3.95 & .809 & High \\
\hline Total of the price factors & 3.87 & .655 & High \\
\hline
\end{tabular}

Table 19 found that overall factors which affect the decision to buy goods or services via the Internet are in high level, having 3.87 as the total average. When analyzing by orders, this study found that highest average is the clearly price of goods and services, having 3.97 as average. The other factors are the facility to pay for the service with average of 3.95, reasonable price compared to the quality with average of 3.85 , cheaper goods and services than other buying methods with average of 3.81, and price comparison between products with average of 3.78 as the smallest average, respectively.

Table 20 found that overall factors of distribution channels which affect the decision to buy goods or services via the Internet are in high level, having 3.89 as the total average. When analyzing by orders, this study found that highest average are easy to use and beautiful modern website, and can order 24 hours a day, having 4.01 as the same average. The other factors are the convenience of the order process with 
average of 3.99, shipment arrival with average of 3.81, and the confidence on security of payment with average of 3.65 as the smallest average, respectively.

Table 20. Average and Standard Deviation of the Distribution Factors That Affect the Decision to Buy Goods or Services via the Internet

\begin{tabular}{|l|c|c|c|}
\hline \multicolumn{1}{|c|}{$\begin{array}{c}\text { the distribution factors that affect the decision to buy goods or } \\
\text { services via the Internet }\end{array}$} & Mean & S.D. & Level \\
\hline easy to use and beautiful modern website & 4.01 & .819 & High \\
\hline the convenience of the order process & 3.99 & .907 & High \\
\hline can order 24 hours a day & 4.01 & .222 & High \\
\hline the confidence on security of payment & 3.65 & .962 & High \\
\hline shipment arrival & 3.81 & .923 & High \\
\hline Total of the distribution factors & 3.89 & .569 & High \\
\hline
\end{tabular}

Table 21. The Average and Standard Deviation of the Marketing Factors That Affect the Decision to Buy Goods or Services via the Internet

\begin{tabular}{|l|c|c|c|}
\hline $\begin{array}{l}\text { the marketing factors that affect the decision to buy goods or services } \\
\text { via the Internet }\end{array}$ & Mean & Lev. & \\
\hline guaranteed delivery and service & 3.86 & .877 & High \\
\hline follow-up or after sales service & 3.59 & .945 & High \\
\hline giveaway & 3.70 & .929 & High \\
\hline points saving for discounts or freebies & 3.46 & 1.020 & Medium \\
\hline sale promotion Total of the marketing factors & 3.70 & .873 & High \\
\hline \multicolumn{1}{|l|}{ High } \\
\hline
\end{tabular}

Table 21 found that overall factors boosting the market which affect the decision to buy goods or services via the Internet are in high level, having 3.66 as the total average. When analyzing by orders, this study found that the highest average are guaranteed delivery and service, with average of 3.86, giveaway or sale promotion with average of 3.70, follow-up or after sales service with average of 3.59, and points saving for discounts or freebies with average of 3.46 , respectively.

Table 22. The Average and Standard Deviation of the Personnel Factors That Affect the Decision to Buy Goods or Services via the Internet

\begin{tabular}{|l|c|c|c|}
\hline $\begin{array}{c}\text { the personnel factors that affect the decision to buy goods or services } \\
\text { via the Internet }\end{array}$ & Mean & S.D. & Level \\
\hline knowledgeable of employees about products and services & 3.74 & .850 & High \\
\hline specialized in solving the problem & 3.58 & .912 & High \\
\hline service quality of employees & 3.66 & .866 & High \\
\hline employees having choices for customers & 3.70 & .849 & High \\
\hline fast service employees & 3.66 & .915 & High \\
\hline Total of the personnel factors & 3.67 & .744 & High \\
\hline
\end{tabular}

Table 22 found that personnel factors which affect the decision to buy goods or services via the Internet are in high level, having 3.67 as the total average. When analyzing by orders, this study found that the highest average are knowledgeable of employees about products and services having 3.74 as average. Other factors are employees having choices for customers with average of 3.70, service quality of employees with average of 3.66, fast service employees with average of 3.66, and specialized in solving the problem with average of 3.58 as the lowest average, respectively.

Table 23 found that the provider processes the factors affect the decision to buy goods or services via the Internet are in high level, having 3.80 as average. When analyzing orderly, this study found that the highest average is beauty website which is easy to use and has clearly details, having 3.90 as average. Other factors are exotic website with average of 3.79 , the reputation of websites with average of 3.79 , prices comparing between products with average of 3.77, and update information with average of 3.76 as the lowest, respectively. 
Table 23. Average and Standard Deviation of the Process Factors Provide Services That Affect the Decision to Buy Goods or Services via the Internet

\begin{tabular}{|l|c|c|c|}
\hline \multicolumn{1}{|c|}{$\begin{array}{c}\text { the process factors provide services that affect the decision to buy } \\
\text { goods or services via the Internet }\end{array}$} & Mean & Level \\
\hline beauty website which is easy to use and has clearly details & 3.90 & .810 & High \\
\hline exotic website & 3.79 & .843 & High \\
\hline the reputation of websites & 3.79 & .852 & High \\
\hline update information & 3.76 & .854 & High \\
\hline prices comparing between products & 3.77 & .867 & High \\
\hline Total of the process factors & 3.80 & .694 & High \\
\hline
\end{tabular}

Table 24. Average and Standard Deviation of the Environmental Factors in Decisions That Affect Buying Goods or Services via the Internet

\begin{tabular}{|c|c|c|c|}
\hline $\begin{array}{l}\text { of the environmental factors in decisions that affect buying goods or } \\
\text { services via the Internet }\end{array}$ & Mean & S.D. & Level \\
\hline $\begin{array}{l}\text { booking or buying goods and services can be done in single step (One } \\
\text { Stop Service) }\end{array}$ & 3.87 & .921 & High \\
\hline secure payment via credit card or e-Banking & 3.82 & .863 & High \\
\hline information service & 3.75 & .867 & High \\
\hline more convenience for old customers & 3.83 & .889 & High \\
\hline security of customer information & 3.77 & .952 & High \\
\hline Total of the environmental factors & 3.81 & .727 & High \\
\hline
\end{tabular}

Table 24 found that environmental factors in decisions that affect buying goods or services via the Internet are in high level, having 3.81 as average. When analyzing orderly, this study found that the highest average is booking or buying goods and services can be done in single step (One Stop Service), having 3.87 as average. Other factors are more convenience for old customers with average of 3.83, secure payment via credit card or e-Banking with average of 3.82, security of customer information with average of 3.77, and information service with average of 3.75 as the lowest, respectively.

\section{Conclusion}

The research about factors that affect the decision to buy goods and services via the Internet on normal program students of Faculty of business administration, Kasem Bundit University, has its summary of the discussion results as follows:

The study found that the majority group of respondents is female aged between of $18-20$ years old, mostly study in Bachelor of business administration in international transportation course. Most of sample groups have monthly income less than 4,000 baht. Most of respondents have their own computers or communication devices that can connect to internet in their private residential area. Most of them use phone/Smart phone connect to Internet. Most of sample group use Internet 3 - 5 hours every day. Mostly, they buy items via the Internet less than 2 times per month.

For behavior about buy goods and services via the Internet, the majority group of respondents buys fashion clothing, shoes, leather, and jewelry. Most of them buy $101-500$ Baht or 1,001 - 2,000 Baht. Most of them also pay by wire transfer to your bank account or via direct debit. About why buy goods and services via Internet, most of respondents buy because of easy to order, giveaway promotions, and have no time to buy at the store. About issues and barriers encountered by buying goods or services via the Internet, most of respondents found that most of the goods are not the same as advertised, there is shipping costs, and some of them get the goods delayed.

Factors that affect the decision to buy goods or services via the Internet on normal program students from faculty of business administration, Kasem Bundit University, can separated to 7 groups of factors. All of them are in high levels. Details as follows:

The first of product factor that affect the decision to buy goods or services via the Internet is the variety 
of goods and services. The first of pricing factors that affect the decision to buy goods or services via the Internet is to clearly identify the goods and services prices. The first of distribution factors that affect the decision to buy goods or services via the Internet is easy to use and beautiful website. The first of marketing factors that affect the decision to buy goods or services via the Internet is the guarantee to deliver goods and services. The first of personnel factors that affect the decision to buy goods or services via the Internet is employees with knowledge of products and services. The first of service process factors that affect the decision to buy goods or services via the Internet is easy to use and beautiful website with clearly details. The first of service environmental factors that affect your decision to buy goods or services via the Internet is the booking or buy goods and services can be done in single step.

\section{Comments and Suggestions}

This study's researchers recommend all online businesses and entrepreneurs, including merchants who sell goods and services on Internet, to take all results of this study as guidelines or recommendation for business planning by considering all factors as follows:

1) If the target group of business is students or people aged between $18-20$ years old, most of them buy fashion clothing, shoes, leather, and jewelry within the budget around $101-500$ or 1,001-2,000 Baht per each transaction for goods and services. Most of them pay by wire transfer to your bank account or pay via direct debit. The reason they buy goods and services on the Internet are convenient to order, promotion, have no time to shop at stores. What you should avoid when you sell goods and services on the internet are products aren't the same as advertised, cost of transportation, and get the goods delayed.

2) The key factors that affect the decision to buy or not buy a product via the Internet are the variety of goods and services, the clearly price of goods and services, easy to use and beautiful website with clear details, no guarantee in the delivery of goods and services, knowledge of employees about products and services, and bookings or buying of goods and services can be done in one single step. All of these are what online stores should recognize in conducting business with their target groups of customers.

A conclusion section is usually required. Although a conclusion may review the main points of the paper, do not replicate the abstract as the conclusion. A conclusion might elaborate on the importance of the work or suggest applications and extensions.

\section{References}

[1] National Statistical Office, Thailand. (2015). Executive summary: The use of information technology and communication in the household. Retrieved from the website: http://service.nso.go.th/nso/nsopublish/themes/files /icthh_exc_58.pdf

[2] National Statistical Office, Thailand. (2014). The survey of e-Commerce status in Thailand. Retrieved from the website: http://service.nso.go.th/nso/nsopublish/ themes/files/electThaiRep 57.pdf

[3] Department of Business Development, Ministry of Commerce. (2011). Standards for the development of e-commerce entrepreneur.

[4] Sirindhorn International Institute of Technology - Thammasat University. (2009). The study of system marketplace on e-Commerce.

[5] King Mongkut's Institute of Technology Ladkrabang. (2013). Progress report no.1, to build credibility in the business of e-commerce. The project development of Thai e-commerce to international standards.

[6] International Institute for Asian Studies, Bangkok University. (2012). Report of the project preparing e-commerce's entrepreneur for supporting the liberalization of e-commerce. 
[7] National Statistical Office, Ministry of Information and Communication Technology, Thailand. (2015). The survey of ICT in enterprises, 2015

[8] Kotler, P. (2000). Marketing Management (10th ed.). New Jersey: Prentice -Hall, Inc.

[9] Schermerhorn, J. R., \& Hunt, J. G. (2000). Organizational Behavior (7th ed.). New York: John Wiley and Sons.

[10] Schiffman, L. G., \& Kanuk, L. L. (2000). Consumer Behavior (7th ed.). New Jersey:Prantice-Hall, Inc.

[11] Schiffman, L. G., Kanuk, L. L. (2004). Consumer Behavior. New Jersey: Pearson Education/Prentice Hall.

[12] William, D. P., \& Jerome, E. (1999). Basic Marketing: A global-Managerial Approach. Boston, MA.: Irwin McGraw-Hill.

[13] Chris, F., \& Karen, E. F. (2005). Business to Business Marketing: Relationships, Systems and Communications. Essex: Prentice Hall / Finacial Times.

[14] Chris, H. (2003). Doing Research Projects in Marketing Management and Consumer Research. London: Routledge.

[15] Ian, P., \& Sui, M. P. (2000). Factors influencing the types of products and services purchased over the Internet. Internet Research, 10(2), 102-113.

[16] Efthymios, C. (2004). Influencing the online consumer's behavior: The Web experience. Internet Research, 14(2), 111-126.

[17] Freestone, O., \& Mitchell, V. (2004). Generation Y attitudes towards e-ethics and internet-related misbehaviours. Journal of Business Ethics, 54(2), 121-128.

[18] Tero, P., Kari, P., Heikki, K., \& Seppo, P. (2004). Consumer acceptance of online banking: An extension of the technology acceptance model. Internet Research, 14(3), 224-235.

[19] Cheung, C. M. K., et al. (2005). A critical review of online consumer behavior: Empirical research. Journal of Electronic Commerce in Organizations, 3(4), 1-19.

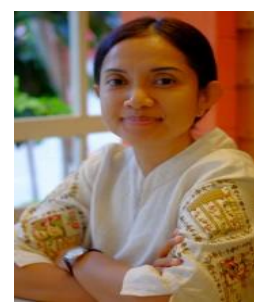

Kitimaporn Choochote is a lecturer in the Department Information Technology and Communication, Faculty of Technology and Environment, Prince of Songkla University Phuket Campus. She received Ph.D in management from University of Pune, India. Her research interests are in e-business, e-HRM, organization management, contemplative education, etc.

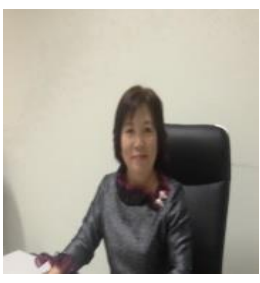

Sureeporn Kiatchalermporn is a lecturer in Faculty of Business Administration, Kasem Bundit University, Bangkok. She graduated the master of accountancy (M.Acc.) (managerial accounting) from Chulalongkorn University. She teaches course in accounting. Her research interests are in accounting, business, teacher education, etc. 